\title{
PENGARUH PENGGUNAAN MODUL PEMBELAJARAN \\ KONTEKSTUAL BERBASIS MULTIPLE REPRESENTATIONS PADA MATERI FLUIDA STATIS TERHADAP KEMAMPUAN BERPIKIR KRITIS SISWA
}

\author{
Sigit Ardiansyah, Chandra Ertikanto, Undang Rosidin \\ Program Studi Pendidikan Fisika, Universitas Lampung \\ Email: sigitardiansyah17@gmail.com
}

Diterima: 9 Juni2018. Disetujui: 4 Juli 2018.

\begin{abstract}
Abstrak
Penelitian ini bertujuan untuk mengetahui pengaruh penggunaan modul pembelajaran kontekstual berbasis multiple representations terhadap kemampuan berpikir kritis. Sampel penelitian ini adalah siswa kelas X IPA 1 dan X IPA 2 SMA Negeri 1 Bandar Surabaya. Penelitian ini dilakukan menggunakan tipe Pretest-Posttest Control Group Design. Data diuji dengan analisis N-gain, Uji Normalitas, Uji Homogenitas Dan Independent Sample T-test. Berdasarkan uji N-gain, nilai rata-rata $\mathrm{N}$-gain kemampuan berpikir kritis pada kelas eskperimen sebesar 0,77 dengan kategori tinggi, sedangkan kelas kontrol dengan kategori sedang sebesar 0,65 , sehingga dapat dinyatakan adanya perbedaan kemampuan berpikir kritis kelas ekperimen dan kelas kontrol. Hasil dari uji nilai Independent Sample T-test nilai Sig. (2-Tailed) kurang dari 0,05 yaitu 0,007, maka dapat dinyatakan terdapat pengaruh yang signifikan penggunaan modul pembelajaran kontekstual berbasis multiple represe ntations terhadap kemampuan berpikir kritis siswa.
\end{abstract}

Kata Kunci: modul pembelajaran kontekstual, multiple represntations, berpikir kritis.

\begin{abstract}
This study aims to determine the effect of using contextual learning module based on multiple representations on critical thinking ability. The sample of this research is the students of class X IPA 1 and X IPA 2 SMA Negeri 1 Bandar Surabaya. This research was conducted using Pretest-Posttest Control Group Design type. Data were tested with analysis N-gain, Normality Test, Homogeneity Test and Independent Sample T-test. Based on thetest $N$-gain, the average value of $N$-gain critical thinking ability in the experimental class is 0.77 with the high category, while the control class with the medium category is 0.65 , so it can be stated that there is a difference of critical thinking ability of the experimental class and class control. Results from the Independent Sample T-test value of the value Sig. (2-Tailed) less than 0.05 is 0.007 , then it can be stated there is a significant influence of the use of contextual learning module based on multiple repetitive ntations on students' critical thinking ability.
\end{abstract}

Keywords: Contextual Learning Module, Multiple Represntations, Critical Thinking. 
Ardiansyah., Ertikanto., Rosidin. - Pengaruh Penggunaan Modul...

\section{PENDAHULUAN}

Fisika merupakan salah satu mata pelajaran yang sangat ditakuti oleh peserta didik karena fisika memerlukan suatu pemahaman yang bagus untuk memahami konsepkonsepnya. Guru dituntut memiliki strategi dalam menciptakan pembelajaran yang aktif dan efektif serta memiliki strategi yang tepat untuk membelajarkan materi fisika agar siswa mampu mencapai indikator yang diinginkan. Pembelajaran pastinya membutuhkan sumber belajar, untuk menunjang pembelajaran kontekstual ini maka diperlukan suatu bahan ajar cetak sehingga mampu mempermudah siswa belajar baik sekolah ataupun di rumah. Mulyasa (2003) menyatakan bahwa tujuan dari penggunaan modul adalah untuk meningkatkan efisiensi dan efektivitas dalam pembelajaran di sekolah, baik waktu, dana, fasilitas, maupun tenaga guru dalam mencapai suatu tujuan pembelajaran yang maksimal.

Menurut Rahayu, Ertikanto, dan Wahyudi (2018), modul dalam pembelajaran sangatlah beguna dalam proses pembelajaran karena modul di dikemas secara utuh dan sistematis, di dalamnya memuat seperangkat pengalaman belajar yang terencana dan didesain untuk membantu siswa menguasai tujuan belajar yang spesifik, materi atau substansi belajar, dan evaluasi. Modul meupakan sarana membantu peserta didik dalam mengaitkan materi dengan kehidupan sehari-hari, sehingga siswa lebih mudah dalam memahami materi yang diajarkan oleh guru dikelas. Modul merupakan salah satu media pembelaran yang menyajikan materi yang tersusun secara sistematis dan utuh, agar peserta didik lebih terarah dan mudah maemahami materi yang dijelaskan oleh guru. Modul juga disusun tidak hanya terususun materi namun modul juga menyajikan contoh soal dll.

Pengertian modul juga didefinisikan oleh hasil penelitian Fatmala, Nyeneng, dan Suana, (2017) yaitu : Modul pembelajaran kontekstual berbasis multirepresentasi memiliki keunggulan, yaitu modul dapat digunakan secara mandiri oleh semua siswa karena produk berupa bahan ajar yang disusun dengan langkah-langkah yang bertahap 
Ardiansyah., Ertikanto., Rosidin. - Pengaruh Penggunaan Modul...

mengikuti sintaks pembelajaran kontekstual, serta disajikan dengan banyak representasi (multirepresentasi) sehingga mempermudah siswa dalam memahami materi. Modul tidak hanya digunakan dalam proses pembelajaran di kelas, namun modul juga dapat digunakan secara mandiri oleh peserta didik dalam mencapai tujuan pembelajaran, sehingga nantinya siswa mampu berkembang dengan sendirinya.

Pembelajaran Kontekstual di era modern ini sangatlah dibutuhkan, karena dengan model pembelajaran ini siswa dituntut untuk lebih mampu menghubungkan materi dengan kehidupan nyata. Menurut Sagala (2013) pembelajaran kontekstual adalah konsep belajar yang membantu guru mengaitkan antara materi yang diajarkannya dengan situasi dunia nyata siswa dan mendorong siswa membuat hubungan antara pengetahuan yang dimilikinya dengan penerapannya dalam kehidupan sehari-hari. Pendapat mengenai penggunaan modul fisika kontekstual menurut Jaya (2012), bahwasannya penggunaan modul fisika kontekstual efektif sebagai bahan ajar untuk meningkatkan hasil belajar siswa

Pendapat mengenai pembelajaran kontekstual juga diungkapkan oleh Rahmi (2014) yaitu penerapan modul kontekstual dalam pembelajaran dapat mendorong siswa untuk menghubungkan antara pengetahuan yang dimiliki dengan penerapan kehidupan sehari-hari, terciptanya suasana pembelajaran yang nyata sehingga siswa aktif dalam memunculkan ide pokok, konsep dari dalam modul maupun menemukan sesuatu yang nyata dalam kehidupan sehari-hari. Adanya pembelajaran yang menyenangkan membuat siswa lebih memahami materi yang terdapat pada modul.

Definisi di atas dapat disimpulkan bahwa pembalajaran kontekstual adalah pembelajaran yang mengaitkan atau mengaplikasikan materi pembelajaran dengan keadaan sekitar atau kehidupan sehari-hari. Materi pembelajaran akan berarti jika peserta didik mempelajari materi pelajaran yang disajikan melalui konteks kehidupan mereka, dan menemukan arti dalam kegiatan pembelajaran, sehingga pembelajaran akan lebih 
Ardiansyah., Ertikanto., Rosidin. - Pengaruh Penggunaan Modul...

berarti dan menyenangkan. multirepresentasi dapat meningkatkan Pembelajaran kontekstual mengarah pemahaman konsep siswa, karena kan peserta didik untuk dalam modul tersebut siswa dapat menyelesaikan suatu permasalahan, belajar dengan beberapa representasi sehingga pesertdidik mampu dan komponen pembelajaran. mengembangkan intelektual, mental, Pendapat tersebut juga diperkuat oleh serta emosionalnya dalam Lestari (2016) yang menyatakan mengaitkan pembelajaran dengan bahwa multirepresentasi dapat dunia nyata.

Multi representasi merupakan cara penyampaian melalui berbagai meningkatkan kemapuan berpikir kritis siswa. Pembelajaran berbasis Multiple representations sadalah cara berbagai cara komunikasi. Artinya, kita dapat menerapkan atau memahami konsep dengan berbagai mengkombinasikan multi representasi dengan strategi maupun model pembelajaran lainnya. Hal ini sesuai dengan pendapat Kohl dan Frankelstein (2007). Multi representasi dapat diajarkan dengan menggunakan pendekatan lebih dari satu.

Pembelajaran berbasis Multiple representations diharapakan mampu meningkatkan kemampuan berpikir kritis siswa, sehingga siswa lebih mudah dalam memecahkan suatu permasalahan. Hal ini sesuai dengan penelitian yang telah dilakukan oleh Verlina, Ertikanto, dan Wahyudi (2018), salah satu bahan ajar berupa modul kontekstual berbasis cara dan bentuk. Baik dalam bentuk matematis, verbal, grafik, gambar, dan lain-lain.

Berpikir kritis merupakan tujuan yang ideal di dalam pendidikan karena mempersiapkan peseta didik untuk kehidupan kedewasaannya, bukan berarti memberikan kepada mereka yang telah siap tetapi mengikusertakan peserta didik di dalam pemenuhan perkembangan dirinya sendiri dan arah dari perkembangan sendiri (self-direction). Berpikir kritis dapat meningkatkan pemahaman konsep siswa sehingga mampu mempengaruhi hasil belajar siswa. Hal ini sejalan dengan hail penelitian yang dilakukan oleh Oktaviani (2016) yang menyatakan 
Ardiansyah., Ertikanto., Rosidin. - Pengaruh Penggunaan Modul...

bahwa adanya hubungan yang signifikan antara kemampuan berpikir kritis dan hasil belajar, artinya apabila siswa memiliki kemampuan berpikir kritis tinggi maka hasil belajarnya juga akan tinggi begitupun sebaliknya

Berpikir kritis merupakan proses terorganisasi yang melibatkan aktivitas mental seperti dalam memecahkan masalah, pembuatan keputusan, dan analisis asumsi. Sementara itu, menurut Wati, Rusmansyah, dan Sholahuddin. (2016). dalam jurnal inovasi pendidikan sains menyatakan bahwa kemampuan berpikir kritis siswa digunakan untuk mengetahui sejauh mana siswa dapat mengaplikasikan proses berpikir kritis khususnya pada indikator merumuskan secara deduktif maupun induktif. Jika siswa mampu mengkonstruksi pemahamannya berdasarkan permasalahan dalam kehidupan sehari-hari yang diberikan, maka siswa dapat mengembangkan keterampilan berpikir kritisnya.

Berdasarakan beberapa pendapat yang telah dikemukakan, dapat diambil kesimpulan bahwa kemampuan berpikir kritis merupakan kemampuan pemecahan masalah yang melatih kemampuan penalaran serta mengharuskan siswa mempunyai alasan-alasan untuk mendukung asumsi ataupun kesimpulan yang diperoleh, yang kemudian digunakan untuk memecahkan permasalahan, hal ini akan berdampak pada proses pengembangan kedewasaannya secara mandiri. Kemampuan berpikir kritis siswa mampu kita tingkatkan dengan berbagai cara, salah satunya yaitu menggunakan modul pembelajaran kontekstual berbasis multiple representations.

Tujuan penelitian ini adalah untuk mendeskripsikan pengaruh penggunaan modul pembelajaran kontekstual berbasis multiple representations terhadap kemampuan berpikir kritis siswa.

\section{METODE}

Populasi dalam penelitian ini adalah kelas XI SMA Negeri 1 Bandar Surabaya semester genap tahun ajaran 2017/2018 yang berjumlah dua kelas atau 63 siswa.. Penelitian ini menggunakan metode True Eksperimental dengan desain penelitian yang digunakan adalah Pretest-Postest Control Group 
Ardiansyah., Ertikanto., Rosidin. - Pengaruh Penggunaan Modul...

Design, yaitu satu kelompok subyek kontrol. Secara umum desain diberi perlakuan khusus (eksperimen), penelitian yang akan digunakan dapat sementara satu kelompok lain dilihat pada Tabel 1.

dijadikan sebaagai kelompok kelas

Tabel 1.Desain Eksperimen Pretest-Postest Control Group Design.

\begin{tabular}{cccc}
\hline Kelas & Pretest & Perlakuan & Postest \\
\hline Eksperimen & $\mathrm{O}_{1}$ & $\mathrm{X}_{1}$ & $\mathrm{O}_{2}$ \\
Kontrol & $\mathrm{O}_{3}$ & $\mathrm{X}_{1}$ & $\mathrm{O}_{4}$ \\
\hline
\end{tabular}

Penelitian ini terdapat dua bentuk variabel, yaitu variabel bebas dan variabel terikat. Variabel bebas dalam penelitian ini adalah penggunaan modul pembelajaran kontekstual berbasis multiple representations, sedangakan variabel terikat yaitu kemampuan berpikir kritis siswa. Intrumen yang digunakan pada penelitian ini adalah lembar tes untuk mengetahui kemampuan berpikir kritis siswa. Tes ini dilaksanakan pada saat pretest dan posttest yang berbentuk soal uraian masing-masing sebanyak 10 butir soal. Sebelum intrumen digunakan dalam sampel, validitas dan reliabilitas soal harus diuji terlebih dahulu.

Data dalam penelitian ini adalah data kemampuan beerpikir kritis siswa yang diperoleh dari proses pembelajaran. Data tersebut kemudian dianaliss menggunagan program SPSS dengan melakukan uji N-Gain, uji Normalitas, uji Homogenitas, dan uji Independent Sample T Test. N-Gain diperoleh dari pengurangan skor tes awal dengan skor tes akhir dibagi oleh skor maksimum dikurangi skor tes awal. Data dari N-gain tersebut kemudian digunakan untuk melihat peningkatan hasil belajar siswa dari kelas kontrol maupun kelas eksperimen, dimana data tersebut harus terdistribusi normal. Dasar pengambilan keputusan dalam uji normalitas, yaitu jika Kolmogorov-Smirnov nilai sig $>0,05$ dikatakan data terdistribusi normal dan jika nilai sig<0,05 data tidak berdistribusi normal. Uji homogenitas dilakukan untuk 
Ardiansyah., Ertikanto., Rosidin. - Pengaruh Penggunaan Modul...

mengetahui sama tau tidaknya varian dari populasi. Jika kedua kelas mempunyai varians yang tidak jauh berbeda (sama) maka kedua kelas dikatakan homogen, begitupun sebaliknya. Apabila kedua kelas homogen, dilakukan uji Independent Sample T-test untuk mengetahui ada atau tidaknya perbedaan peningkatan kemampuan berpikir kritis siswa dari kedua kelas. Berpedoman berdasarkan nilai signifikansi atau nilai probabilitas, jika nilai sig $>0,05$ maka H0 diterima dan apabila nilai sig $<0,05$ maka H0 ditolak.

\section{HASIL DAN PEMBAHASAN}

Penelitian pembelajaran mengguna-kan modul pembelajaran kontekstual berbasis multiple representations pada materi fluida statis ini mulai dilaksanakan pada tanggal 26 Maret 2018 dan berakhir pada tanggal 5 April 2018 di SMA Negeri 1 Bandar Surabaya. Proses pembelajaran berlangsung selama 3 kali tatap muka dengan alokasi waktu 6 jam pelajaran yang terdiri atas 45 menit pada setiap jam pelajarannya. Kelas eksperimen pada penelitian ini adalah kelas XI IPA 1 dengan 30 siswa sedangkan kelas kontrik adalah kelas XI IPA 2 sebanyak 33 siswa. Hasil yang diperoleh dari penelitian

Instrumen tes yang berupa soal pretest dan soal posttest terlebih dahulu diuji untuk mengetahui layak atau tidaknya soal digunakan. Uji instrumen ini adalah uji validitas dan reliabilitasnya Pengujian ini dilakukan diluar sampel penelitian, yaitu terhadap 22 siswa kelas XII IPA SMA Negeri 1 Bandar Surabaya yang telah belajar mengenai materi fluida statis dengan jumlah soal sebanyak 15 soal essay. terdPt 10 soal yang valid dan 5 soal yang tidak valid. Selanjutnya soalang di ujikan tersebut di ujilagi yaitu uji reliabilitas dan diperoleh bahwa soal sangat reliabel karena nilai Cronbach's Alpha sebesar 0,840 .

Peningkatan kemampuan berpikir kritis siswa dapat dilihat dari selisih antara hasil tes setelah diberi perlakuan dengan hasil tes sebelum diberi perlakuan. Rata-rata N-gain kemampuan berpikir kritis siswa kelas eksperimen sebesar 0,77 dengan kategori tinggi dan untuk kelas control sebesar 0,65 dengan kategori sedang. Hal ini dapat menunjukkan 
Ardiansyah., Ertikanto., Rosidin. - Pengaruh Penggunaan Modul...

bahwa adanya pengaruh penggunaan modul pembelajaran kontekstual berbasis multiple representations pada materi fluida statis.

Uji normalitas data dilakukan untuk mengetahui apakah data $\mathrm{N}$-gain dari pada kedua kelas eksperimen dan kontrol berdistribusi normal atau tidak. 0,05 yaitu 0,814 pada kelas eksperimen dan 0,997 pada kelas kontrol. Hasil ini merupakan salah satu syarat terpenuhinya untuk melakukan uji 2 sampel bebas dengan menggunakan Independent Sample Ttest.

Tabel 2. Hasil Uji Normalitas Skor $N$-gain

\begin{tabular}{lcc}
\hline Parameter & Kelas Eksperimen & Kelas Kontrol \\
\hline Asymp. Sig (2-tailed) & 0,814 & 0,997 \\
\hline
\end{tabular}

Setelah uji normalitas, data diuji dengan program SPSS

homogenitas untuk mengetahui apakah varian data adalah sama atau tidak. Uji ini dilakukan sebagai prasyarat dalam analisis Independent Sample T-test. Uji ini dilakukan menggnakan Homogeneity of Variances pada One Way Anova. Variabel yang diuji homogenitasnya adalah $\mathrm{N}$-gain rata-rata dari masingmasing kelas.

Tabel 3. Hasil Uji Homogenitas $N$-gain

\begin{tabular}{llll}
\hline Levene Statistic & $\boldsymbol{d f 1}$ & $\boldsymbol{d f 2}$ & Sig. \\
\hline 0.009 & 1 & 60 & 0.608 \\
\hline
\end{tabular}

Dari Tabel 3 dapat diketahui bahwa nilai sig. 0,608, karena signifikansi 0,608 lebih besar dari 0,05 maka dapat disimpulkan bahwa kedua kelompok data mempunyai varian yang sama atau homogen.
Setelah melakukan uji normalitas skor N-gain dan Uji Homogenitas dari kelas eksperimen dan kontrol tersebut, selanjutnya dilakukan pengujian dua sampel bebas menggunakan Independent Sample Ttest untuk mengetahui ada tidaknya 
Ardiansyah., Ertikanto., Rosidin. - Pengaruh Penggunaan Modul...

perbedaan rata-rata kemampuan adalah perbedaan rerata $\mathrm{N}$-gain dari berpikir kritis siswa sebelum dan masing-masing kelas eksperimen. sesudah dilakukan pembelajaran pada masing-masing kelas eksperimen dan Hasil Uji Independent Sample T-test ditampilkan pada tabel 4 .

kelas kontrol. Adapun yang diuji

Tabel 4. Hasil Uji Independent Sample T-test

\begin{tabular}{cccc}
\hline & & \multicolumn{2}{c}{ Gain } \\
\cline { 3 - 4 } & & $\begin{array}{c}\text { Equal Variances } \\
\text { Assumed }\end{array}$ & $\begin{array}{c}\text { Equal Variances } \\
\text { Not Assumed }\end{array}$ \\
\hline $\begin{array}{c}\text { t-test for } \\
\text { equality of } \\
\text { Means }\end{array}$ & $\mathrm{T}$ & 2,781 & 2,773 \\
& $\begin{array}{c}\text { Df } \\
\text { Sig (2- } \\
\text { tailed) }\end{array}$ & 60 & 58,530 \\
\hline
\end{tabular}

Berdasarkan Tabel 4, nilai gain kemampuan berpikir kritis kelas signifikansi $(0,007<0,05)$ maka H0 eksperimen lebih tinggi dibandingkan ditolak. Berdasarkan hasil pengujian rata-rata $\mathrm{N}$-gain kemampuan berpikir tersebut, maka dapat disimpulkan kritis kelas kontrol. Hal ini dapat bahwa terdapat pengaruh yang terlihat berdasarkan hasil perhitungan siginifikan ketika pembelajaran rata-rata $\mathrm{N}$-gain kelas eskperimen mengggunakan modul pembelajaran sebesar 0,77 dengan kategori tinggi. kontekstual berbasis multiple Sedangkan pada kelas kontrol ratarepresentations terhadap kemampuan berpikir kritis.

Berdasarkan hasil uji hipotesis menggunakan uji Independent Sample T-test maka dapat diketahui bahwa terdapat perbedaan rata-rata kemampuan berpikir kritis siswa pada kelas eksperimen dan kelas kontrol secara signifikan, dimana rata-rata $\mathrm{N}$ rata $\mathrm{N}$-gain kemampuan berpikir kritis siswa sebesar 0,65 dengan kategori sedang. Hal ini berarti terdapat pengaruh yang signifikan dari penggunakan modul pembelajaran kontekstual berbasis multiple representations terhadap kemampuan berpikir kritis siswa. Ngain kemampuan berpikir kritis siswa 
Ardiansyah., Ertikanto., Rosidin. - Pengaruh Penggunaan Modul...

diperoleh dari data hasil penggunaan instrumen tes berupa pretest dan posttest. Rata-rata kemampuan berpikir kritis diambil sebelum dan setelah diterapkannya pembelajaran menggunakan penggunakan modul pembelajaran kontekstual berbasis multiple representations dan pembelajaran tanpa modul pembelajaran kontekstual berbasis multiple representations. Grafik ratarata pretest dan posttest kemampuan berpikir kritis dapat dilihat pada gambar 1.

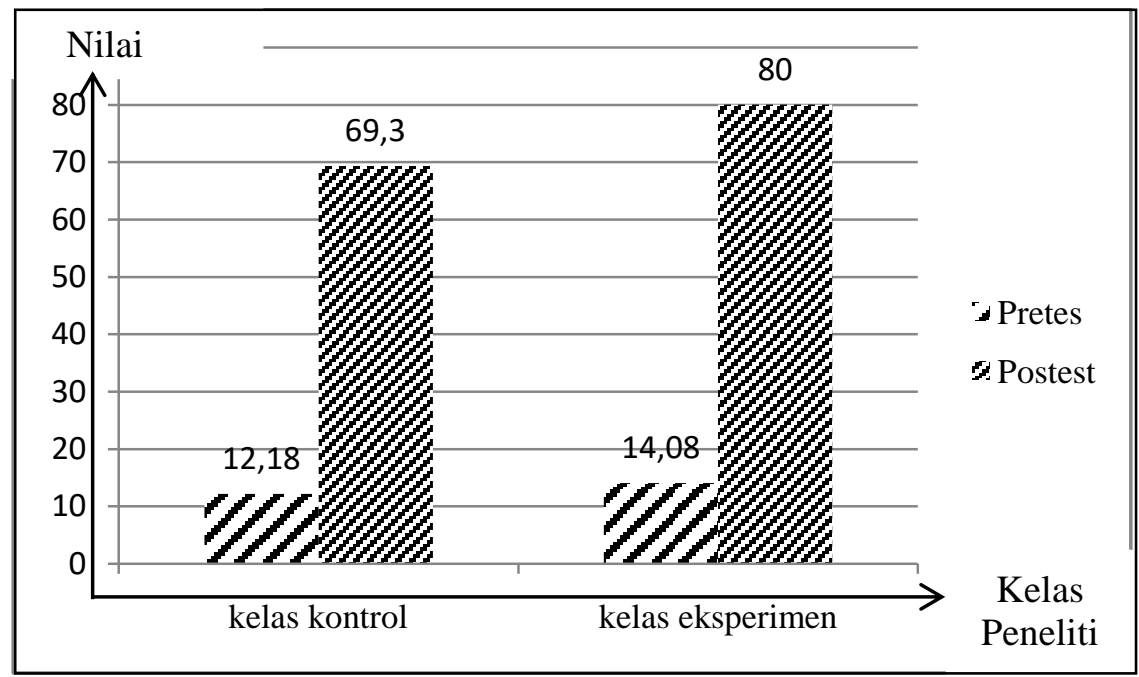

Gambar 1. Grafik Rata-Rata Pretest dan Posttest Kemampuan Berpikir Kritis

Data pada kelas eksperimen, ratarata kemampuan berpikir kritis sebelum diterapkan pembelajaran dengan menggunakan modul pembelajaran kontekstual berbasis multiple representations hanya sebesar 14,08, setelah diberikan perlakuan kemampuan berpikir kritis siswa meningkat menjadi 80 . Terjadi peningkatan rata-rata kemampuan berpikir kritis siswa sebesar 65,92 setelah diterapkan pembelajaran dengan menggunakan modul pembelajaran kontekstual berbasis multiple representations. Hal yang sama terjadi pada kelas kontrol. Pada kelas kontrol, rata-rata kemampuan berpikir kritis siswa sebelum diterapkan pembelajaran hanya sebesar 12,18, setelah diterapkan pembelajaran rata-rata kemampuan berpikir kritis nya meningkat menjadi 69,3. Terjadi peningkatan rata-rata 
Ardiansyah., Ertikanto., Rosidin. - Pengaruh Penggunaan Modul...

peningkatan berpikir kritis siswa sebesar 57,12 .

Kelas eskperimen memiliki Ngain kemampuan berpikir kritis lebih tinggi. Berdasarkan hasil perhitungan diketahui bahwa pada kelas eksperimen siswa yang memperoleh kategori tinggi sebanyak 20 siswa $(66,67 \%)$, kategori sedang 10 Siswa $(33,33 \%)$, dan 0 siswa $(0,00 \%)$ memperoleh kategori rendah. Sedangkan pada kelas kontrol, siswa yang memperoleh kategori tinggi sebanyak 12 siswa $(37,50 \%)$, ketegori sedang 19 siswa $(59,38 \%)$, dan siswa yang mendapatkan kategori rendah sebanyak 1 siswa $(3,12 \%)$.

Perbedaan nilai rata-rata kemampuan berpikir kritis pada masing-masing kelas dapat dilihat dari proses guru dalam menyampaikan materi pembelajaran. Pada kelas eksperimen guru menggunakan modul pembelajaran kontekstual berbasis multiple representations. Modul pembelajaran kontekstual berbasis multiple representations ini memiliki beberapa representasi penyampaian materi yang membuat pemaham an konsep siswa lebih cepat untuk memahaminya. Hal ini didukung oleh hasil penelitian Suhandi (2012), yaitu bahwa pendekatan pembelajaran multirepresentasi yang digunakan memiliki efektivitas yang tergolong tinggi dalam menanamkan konsepkonsep yang tercakup dalam materi fisika

Salah satu keunggulan modul pembelajaran kontekstual berbasis multiple representations yaitu pada proses pembelajarannya siswa akan dibantu dengan beberapa contoh fenomena permasalahan dalam kehidupan sehari-hari yang disajikan dengan menarik, sehingga siswa lebih tertarik untuk mengikuti proses pembelajaran dan mampu memecahkan suatu permasalahan itu sendiri. Hal ini didukung oleh hasil penelitian yang diungkapkan oleh Rahmi (2014). Penerapan modul kontekstual dalam pembelajaran dapat mendorong siswa untuk menghubungkan antara pengetahuan yang dimiliki dengan penerapan kehidupan sehari-hari, terciptanya suasana pembelajaran yang nyata sehingga siswa aktif dalam memunculkan ide pokok, konsep dari dalam modul maupun menemukan 
Ardiansyah., Ertikanto., Rosidin. - Pengaruh Penggunaan Modul...

sesuatu yang nyata dalam kehidupan sehari-hari. Adanya pembelajaran yang menyenangkan membuat siswa lebih memahami materi yang terdapat pada modul.

Selain itu juga dalam keunggulan modul pembelajaran kontekstual berbasis multiple representations ini ialah ditampilkannya contoh peristiwa dalam kehidupan sehari-hari, beserta soal-soal evaluasi untuk mengetahui sejauh mana siswa dalam memahami materi yang telah diberikan yang semua itu di tampilkan dalam beberapa representasi seperti gambar, grafik, tabel, grafik dll. Berdasarkan uji yang telah dilakukan penggunaan modul pembelajaran kontekstual berbasis multiple representations dirasa mampu untuk meningkatkan kemampuan berpikir kritis siswa, karena terdapat perbedaan yang signifikan antara kelas eksperimen dan kelas kontrol. Hal ini sesuai dengan penelitian Khotimah, Nyeneng, dan Sesunan (2017) bahwa pembelajaran dengan multirepresentasi mampu untuk menjembatani proses pemahaman siswa terhadap konsep-konsep fisika sehingga dapat meningkatkan kemampuan berpikir kritis siswa dan dapat meningkatkan hasil be lajar siswa.

\section{KESIMPULAN DAN SARAN}

\section{Kesimpulan}

Berdasarkan data hasil penelitian dan pembahasan, maka dapat disimpulkan bahwa terdapat pengaruh penggunaan modul pembelajaran kontekstual berbasis multiple representations terhadap kemampuan berpikir kritis siswa secara signifikan, hal itu dapat dilihat dari peningkatan kemampuan berpikir kritis siswa setelah menggunakan modul pembelajaran kontekstual berbasis multiple representations. Nilai $\mathrm{N}$-gain pada kelas eksperimen sebesar 0,77 dengan kategori tinggi, sedangkan $\mathrm{N}$ gain kelas kontrol sebesar 0,65 dengan kategori sedang, sehingga dapat dinyatakan adanya perbedaan kemampuan berpikir kritis kelas ekperimen dan kelas kontrol. Hasil dari uji nilai Independent Sample Ttestnilai Sig. (2-Tailed) kurang dari 0,05 yaitu 0,007, maka dapat dinyatakan bahwa terdapat pengaruh yang signifikan penggunaan modul pembelajaran kontekstual berbasis 
Ardiansyah., Ertikanto., Rosidin. - Pengaruh Penggunaan Modul...

multiple representations terhadap

kemampuan berpikir kritis siswa.

\section{Saran}

Pertama pembelajaran dengan meng-gunakan modul pembelajaran kontekstual berbasis multiple representations dapat dijadikan salah satu alternatif bagi guru di sekolah dalam upaya meningkatkan kemampuan berpikir kritis siswa. Kedua pada pengguaan modul pembelajaran kontekstual berbasis multiple representations, perlu diperhatikan yaitu penggunaan waktu ketika menggunaan modul tersebut, agar proses penyampaian materi kepada murid efisien. Selain itu, suasana kelas juga perlu diperhatikan. Guru harus mampu membawa siswa agar tidak cepat bosan ketika kegiatan belajar mengajar berlangsung.

\section{DAFTAR PUSTAKA}

Fatmala, N. E., Nyeneng, I. D. P., \& Suana, W. (2017). Pengembangan Modul Kontekstual Berbasis Multirepresentasi Pada Materi Hukum Newton Tentang Gravitasi. Jurnal Pembelajaran Fisika, 5(4).

Jaya, S. P. S. (2012). Pengembangan modul fisika kontekstual untuk meningkatkan hasil belajar fisika peserta didik kelas $\mathrm{X}$ semester $2 \mathrm{di}$ SMK Negeri 3 Singaraja. Jurnal

\section{Teknologi}

Pembelajaran Indonesia, 1(2).

Khotimah, K., Nyeneng, I. D. P., \& Sesunan, F. (2017). Pengaruh Kemampuan Berpikir Kritis Dan Respons Bahan Ajar Multirepresentasi Terhadap Hasil Belajar. Jurnal Pembelajaran Fisika, 5(3).

Kohl, P. B., Rosengrant, D., \& Finkelstein, N. D. (2007). Strongly and weakly directed approaches to teaching multiple representation use in physics. Physical Review Special Topics-Physics Education Research, 3(1), 010108.

Lestari, L. (2016). Penerapan Pendekatan Multi Representasi terhadap Kemampuan Kognitif Siswa pada Materi Sistem Ekskresi. Jurnal Pendidikan Biologi, 4(4), 1-12.

Mulyasa, E. (2003). Kurikulum Berbasis Kompetensi: Konsep, Karakteristik, dan Implementasi. Bandung: Remaja Rosdakarya.

Oktaviani, S. (2016). Pengaruh Kemampuan Berfikir Kritis pada Penggunaan LKS Discovery Learning terhadap Hasil Belajar. Jurnal Pembelajaran Fisika, 4(4), 61-70.

Rahayu, S. M., Ertikanto, C., \& Wahyudi, I. (2018). Pengaruh Pengunaan Modul Kontekstual Berbasis Multirepresentasi Pada Pembelajaran Hukum Gravitasi Newton Terhadap Hasil Belajar Siswa. Jurnal Pembelajaran Fisika, 6(1).

Yerita, H., Haviz, M., \& Rahmi, E. (2014). Efektivitas Penggunaan Modul Pembelajaran Biologi 
Ardiansyah., Ertikanto., Rosidin. - Pengaruh Penggunaan Modul...

Berbasis Kontekstual Pada Pokok Bahasan Ekosistem Siswa Kelas X di SMAN 1 Rambatan. Edusainstika, 1(1).

Sagala, S. (2013). Konsep dan Makna Pembelajaran. Bandung: Alfabeta.

Suhandi, A., \& Wibowo, F. C. (2012). Pendekatan multirepresentasi dalam pembelajaran usaha-energi dan dampak terhadap pemahaman konsep mahasiswa. Jurnal Pendidikan Fisika Indonesia, 8(1).

Verlina, A. A., Ertikanto, C., \& Wahyudi, I. (2018). Pengaruh
Penggunaan Modul Kontekstual Berbasis Multirepresentasi Pada Pembelajaran Hukum Gravitasi Newton Terhadap Pemahaman Konsep Siswa. Jurnal Pembelajaran Fisika, 6(1).

Wati, R., Rusmansyah, R., \& Sholahuddin, A. (2016). Meningkatkan Kemampuan Berpikir Kritis dan Hasil Belajar Siswa Kelas Xi IPA 2 SMA PGRI 4 Banjarmasin Pada Konsep Sistem Koloid Melalui Model Problem Based Learning. Quantum: Jurnal Inovasi Pendidikan Sains, 5(2). 